\title{
Heat stress in symbiotic dinoflagellates: signalling towards life or death?
}

\author{
Jerome Delamare-Deboutteville ${ }^{1}$, Sophie Dove ${ }^{2}$, and Nedeljka Rosic ${ }^{3}$ \\ ${ }^{1}$ WorldFish Center \\ ${ }^{2}$ University of Queensland \\ ${ }^{3}$ Affiliation not available
}

May 8, 2020

\begin{abstract}
Global warming may detrimentally affect symbiosis between dinoflagellates and other marine invertebrates. Heat stress has been found to induce cellular changes possibly via epigenetic modifications, including DNA methylation. In this project, we exposed symbiotic dinoflagellates to hyper-thermal conditions $\left(+7^{\circ} \mathrm{C}\right)$ in the presence of a DNA methylation inhibitor, the drug 5-AZA-2'-deoxycytidine (5-AZA). We monitored the early signs of oxidative stress and physiological changes in dinoflagellates cultures in vitro. Real-time analyses of the production of reactive oxygen species (ROS) and antioxidant, reduced glutathione (GSH) were performed in living dinoflagellate cells using flow cytometry. After $24 \mathrm{~h}$ of thermal stress, a $34 \%$ reduction in the algal density was noted only in the presence of DNA methylation inhibitor, while the opposite trend was reported in the cultures without 5-AZA, with a $33 \%$ increase in cell numbers. Our results revealed the negative effect of DNA methylation inhibitor drug on Symbiodiniaceae density and the size of cells when exposed to rising temperatures indicating the importance of DNA methylation for symbiotic dinoflagellates response to heat stress. Consequently, the plasticity of algal symbionts to adapt and survive in a thermally challenging marine environment may partially be influenced by DNA methylation.
\end{abstract}

\section{INTRODUCTION}

Coral reefs are the most diverse marine ecosystems, currently threatened by climate change. Unicellular dinoflagellate algae (from the familySymbiodiniaceae ) build mutualistic symbioses with corals and other cnidarian hosts, which are essential for the survival of coral-reef ecosystems. In the mutualisms, a nutrient exchange allows for successful interaction between microbial symbionts and the host organism. In the case of cnidarian-dinoflagellates symbiosis such as found in the case of reef-building corals, the productivity of the coral host heavily depends on the effective performance of this mutualistic symbiosis (Muscatine et al. 1975, Muscatine \& Porter 1977, LaJeunesse et al. 2018). Corals absorb inorganic elements from the external environment, which are then transferred to algae, and in return, organic compounds synthesised through photosynthesis by dinoflagellates are provided to corals (Gattuso et al. 1999, Yellowlees et al. 2008, Gordon \& Leggat 2010). The stability of this delicate partnership between corals and dinoflagellates is negatively influenced by changes happening in their external environment (Hoegh-Guldberg et al. 2017, Camp et al. 2018, Hughes et al. 2020). Thermal stress is one of the leading environmental factors known to destabilise the symbiosis between corals and their dinoflagellate symbionts, resulting in the loss of the algal symbionts from the coral tissue and/or pigments bleaching (Gates et al. 1992, Hoegh-Guldberg 1999, Hoegh-Guldberg et al. 2007b, Weis \& Allemand 2009). Coral bleaching can be visually observed, while the earliest changes are detectable at the molecular level inside the coral tissue and within their algal symbionts (Rosic et al. 2014). Exposure to elevated temperatures and ultraviolet radiation has been found to result in oxidative stress response in Symbiodinaceaedinoflagellates, due to increased production of superoxide radicals and a decrease in the algal photosynthetic efficiency (Lesser 1996). Robust antioxidant capacities are critically 
important to protect the cellular structures of dinoflagellates and many other organisms from oxidative damages (Martindale \& Holbrook 2002, Lesser 2006, Krueger et al. 2014, Levin et al. 2016a). Importantly, several conversed antioxidant genes were identified among four different types of symbiotic dinoflagellates (Rosicet al. 2015). When corals were exposed to heat stress, the production of ROS happened in symbiotic dinoflagellates and destabilised the coral-alga symbiosis (Douglas 2003, Richier et al. 2005). InSymbiodinaceae dinoflagellates, the leakage of ROS from cells with a decrease in the photosynthetic efficiency has been recognised as a sign of physiological stress (Richier et al. 2005). When coral holobiont is exposed to hyperthermal conditions, the initial place of ROS production happens in algal cells living within the tissue of the coral host, resulting in destabilizing the functionality of coral-algal symbiosis (Hoegh-Guldberg et al.2007a, Weis \& Allemand 2009). However, the disruption of cnidarian host mitochondria leading to dysfunction of the host-algal symbiosis was also reported to be the first place of early damage (Dunn et al. 2012). Recent findings suggest that without severe photosystem damage, the heat-induced algal ROS production and leakage were not leading to symbiont expulsion from the host tissue (Nielsen et al. 2018).

In response to heat stress, coral dinoflagellates are undergoing complex cellular changes starting with numerous differential gene expression affecting molecular chaperones, haemoglobin-like genes, cytochrome P450s, photosynthesis and oxidative stress-related genes (Rosic et al. 2010, Leggat et al. 2011, Rosic et al. 2011a, Rosic et al. 2013, Krueger et al. 2014, Krueger et al. 2015, Levin et al. 2016a, Gierz et al. 2017, Salas BH 2017). Beyond transcriptomics, epigenetic changes may determine the susceptibility of the organism to stress (Tammen et al. 2012) and its symbiotic status (Li et al.2018). Within the eukaryotic genome, epigenetic modifications on DNA or chromatin proteins may affect gene transcription and gene silencing (Suzuki \& Bird 2008). DNA methylation, the addition of a methyl group to DNA, is a key epigenetic mechanism, besides histone modifications, that is influenced by environmental stress (Chodavarapu et al. 2012), and is altering cellular phenotypes (Winnefeld \& Lyko 2012, Eirin-Lopez \& Putnam 2019). As a result, specific gene expression patterns and phenotypic changes could be observed without introducing any mutation or modifications within the DNA code. In reef-building corals, DNA methylation was found to be influenced by parental environment and developmental status (Liew et al. 2020). Long-term $\mathrm{pH}$ stress resulted in changes in DNA methylation patterns affecting cell cycle in the coral Stylophora pistillata(Liew et al. 2018). Unique DNA methylation patterns were discovered in symbiotic dinoflagellates with the majority of the genome being methylated at CG dinucleotides (de Mendoza et al. 2018). However, it is still not clear how epigenetic mechanisms may modify the ability of Symbiodinaceae to tolerate thermal stress.

In this study, we aimed to examine, for the first time, the physiological performance of Symbiodinaceae under heat stress and DNA methylation compromised conditions using multiple parameters including algal pigments, cell density, cell viability and cellular morphology. In parallel, the oxidative stress response was assessed via the measurements of the changes in ROS (hydrogen peroxide and superoxide anion) and antioxidant, reduced glutathione levels inSymbiodinaceae cultures exposed to elevated temperatures $\left(32^{\circ} \mathrm{C}\right)$ with and without the addition of the DNA methylation inhibitory drug.

\section{MATERIALS AND METHODS}

\section{Algal culture}

Cultures of Symbiodinaceae dinoflagellates (Fig. 1 ) were obtained from Professor Roberto Iglesias-Prieto (RSU Puerto Morelos, UNAM, Mexico) and were kept in culture for more than 5 years at $25^{\circ} \mathrm{C}$. These dinoflagellate cultures were isolated from Oculina diffusa(Bermuda) and were identified as polyclonal cultures of clades B (internal transcribed spacer [ITS2] type B2). Based on a new taxonomy, old Symbiodinium clade B now belongs to the genusBreviolum (LaJeunesse et al.2018).

Axenic algal cultures were grown in $\mathrm{f} / 2$ medium (Guillard \& Ryther 1962). The maintenance of cultured microalgae was done at $25^{\circ} \mathrm{C}, 12: 12$-h day-night period, with a maintenance irradiance of $\sim 50 \mu \mathrm{mol}$ quanta photon $\mathrm{m}^{-2} \mathrm{~s}^{-1}$ (measured using a Li-Cor flat quantum sensor). The culturing temperature used represents a typical average of the Spring/Fall temperatures for the region. Before the start of the experiment, cultures were acclimatised to the low light level of $\sim 25 \mu \mathrm{mol}$ quanta photons $\mathrm{m}^{-2} \mathrm{~s}^{-1}$ for a 24 -h period. 


\section{Experimental design}

During the exponential phase (cell number ${ }^{\sim} 10^{6-7}$ per ml) Symbiodinaceaecultures were exposed to control $25^{\circ} \mathrm{C}$ and elevated temperatures of $32^{\circ} \mathrm{C}$ (incrementally increased for $1^{\circ} \mathrm{C}$ per $\frac{1}{2} \mathrm{~h}$ until reaching $32^{\circ} \mathrm{C}$ ) for up to 5 days under $12 \mathrm{~h}: 12 \mathrm{~h}$ light-dark cycle with an experimental irradiance of $\sim 25 \mu \mathrm{mol}$ quanta photons $\mathrm{m}^{-2} \mathrm{~s}^{-1}$ $(\mathrm{n}=5)$. The $32^{\circ} \mathrm{C}$ temperature represents an increase of $7^{\circ} \mathrm{C}$ compared to a normal daily culture maintenance temperature and was chosen to enable thermal stress and bleaching of algal pigments to occur within the 5 -day period of the experiment. These are ecologically relevant temperatures as ambient temperatures of $25-26^{\circ} \mathrm{C}$ were reported during summer months on the reef flat at Heron Island (GBR, Australia). Reef field temperatures recorded for Oculina diffusa ranged from $13-31^{\circ} \mathrm{C}$ with an average of $24.6^{\circ} \mathrm{C}$ as reported by the Smithsonian Marine Station (Florida, USA) (Dineen 2001).

The drug 5-AZA-2'-deoxycytidine (5-AZA) is a specific inhibitor of DNA methylation that can only be incorporated into DNA strands with a working concentration recommended by the manufacturer to be between 0.1-10 $\mu \mathrm{M}$ (InvivoGen USA). Before the experiment, algal cultures were exposed to a range of concentrations from 0-10 $\mu \mathrm{M}$ (drug titration) over 5 days under control temperature to establish the optimal working 5-AZA concentration. No changes in symbiont density were observed with and without 5-AZA and the highest recommended working concentration of $10 \mu \mathrm{M}$ was used for further experiments. Half of the cultures from control and treatment temperatures were supplemented with DNA methylation inhibitor 5-AZA at a final concentration of $10 \mu \mathrm{M}$. Samples were gently aerated throughout exposure time to maintain appropriate oxygen levels. For monitoring pigment concentrations in algal cells, samples were collected at days 1, 3 and 5 , by taking $3 \mathrm{~mL}$ aliquots from each biological replicates $(\mathrm{n}=5)$ that were further processed for pigment extraction. For monitoring oxidative changes, cell morphology and viability using flow cytometry, another $3 \mathrm{~mL}$ aliquots were taken from three biological replicates $(\mathrm{n}=3)$ at each time point and processed further analyses.

Cell density and pigment composition

The algal pigment extraction was done using $3 \mathrm{~mL}$ of cultures aliquot, following the steps: centrifugation of the aliquots (4000 $x \mathrm{~g}$ for $5 \mathrm{~min}$ ), re-suspension of the pellet in $1 \mathrm{~mL}$ of $100 \%$ cold methanol, followed by 10 min sonication on ice-cold water and centrifugation (4000x $g$ for $5 \mathrm{~min})$. Each supernatant was transferred to a new tube and kept on ice. An additional $1 \mathrm{~mL}$ of $100 \%$ cold methanol was added to the pellet and the pigment extraction step was repeated until all pigment extracts were removed from the pellet (usually after 3 subsequent rounds). The filtered pigment extractions $(0.45 \mu \mathrm{m})$ were used for pigment separation in a Shimadzu SCL - 10 HPLC linked to a Shimadzu SPD - M10A photodiode array detector, using the column and method described by Zapata and team (Zapataet al. 2000) using as solutions: A (methanol: acetonitrile: ammonium acetate, 50:25:25 v:v:v) and B (methanol: acetonitrile: acetone, 20:60:20 v:v:v). Pigments concentrations (in picograms) were obtained using the appropriate standards and normalised per cell. The cell numbers were calculated before pigment extraction using the TC20 Automated Cell Counter (Bio-rad). A total cell count was obtained without trypan blue, while live cell counts were done with trypan blue staining (TC10 Trypan Blue Dye, 0.4\% solution, Bio-rad).

Confocal microscopy

Autofluorescent emission spectra of algal cells were assessed by confocal microscopy (Zeiss LSM 710). Cells suspension was concentrated by centrifugation $(300 \times g$ for $5 \mathrm{~min}$ ) and placed onto a double concave slide with a high performance $1 \frac{1}{2}$ cover glass (Zeiss). Cells were observed using an objective 20x and excited with four different lasers $(405,488,561$ and $633 \mathrm{~nm})$.

\section{Flow cytometry}

\section{Instrument and analysis}

Samples were analysed using the BD LSRII (Bioscience, USA) analysing flow cytometer that can simultaneously detect up to 18 different colours. The instrument was equipped with five individual lasers (UV, 407, 488,561 and $633 \mathrm{~nm}$ ). Due to the high level of autofluorescence coming from algal cells, unstained control 
samples without dyes were included for the viability, apoptosis and reactive oxygen species experiments. The baseline fluorescence level of each unstained control was removed from the corresponding channel used for each of the dye. All specifications were summarised in Table 1 . Data acquisition was performed on the BD FACSDiva software and analyses were performed using the FlowJo software (10.0.8r1).

Cell enumeration and autofluorescence

Both autofluorescence and cell enumeration analyses were carried out by flow cytometry in the same tube and at the same time. For cell count, $10 \mu \mathrm{L}$ of $10-\mu \mathrm{m}$ beads (Beckman Coulter Flow count fluorospheres PN No. 7548156, USA) assayed at a concentration of 992 beads/ $\mu \mathrm{L}$ were added to $90 \mu \mathrm{L}$ aliquot of each sample to estimate the concentration of algal cells owing to their similar fluorescence intensity and cell size (14 to $18-\mu \mathrm{m})$. Accumulation bodies, debris, cell doublets, and aggregates were gated out from analyses (Figure S1 ). Briefly, algal cells concentration per $\mathrm{mL}$ was calculated using 1000 beads set as the stopping gate during data acquisition on the instrument, and the known concentration per $\mathrm{mL}$ of the commercial beads according to the equation from Olson et al. $1993\left[\right.$ cell $\mathrm{mL}^{-1}=$ (cell counted/beads counted $) *$ beads $\mathrm{mL}^{-1}$ ] (Olson RJ 1993). Red fluorescence signals from chlorophyll a (Olson et al. 1989, Premazzi et al. 1989) were collected via $660 \pm 20$-nm red band-pass filters, whereas green fluorescence signals from $\beta$-carotene (Anet al. 1991, An et al.2000) were collected via FITC $530 \pm 30$-nm bandpass filter. Briefly, cells from each sample were excited with five individual lasers (UV, 407, 488, 561, $633 \mathrm{~nm}$ ) and the autofluorescence emission signals collected using the 18 channels available on the instrument. The respective band-pass filter voltages for each laser were presented inSupplementary Table 1 . All parameters were recorded in the logarithmic scale with all area (A), width (W) and height (H) selected. The threshold was set on the forward scatter (FSC) at $500 \mathrm{~V}$. All samples were kept on ice protected in dark until being analysed by flow cytometry.

Morphological characterization

Both cell size and internal complexity were used as proxies to get information about the physiological state of algal cells during thermal stress and exposure to DNA methylation inhibitor. Morphology parameters of the cells (size and internal complexity) were assessed according to their value in forward (FSC) and side scatters (SSC) respectively and were expressed in arbitrary units (A. U.).

Mortality and apoptosis assay

The following protocol were optimised and adapted from the commercial kit: annexin V Pacific Blue conjugate for apoptosis detection (Invitrogen, Australia). Briefly, annexin-binding buffer: $10 \mathrm{mM}$ HEPES, $140 \mathrm{mM}$ $\mathrm{NaCl}$, and $2.5 \mathrm{mM} \mathrm{CaCl}_{2}, \mathrm{pH} 7.4$ was prepared. Cell stress was induced by exposure of the algal cells to elevated temperatures. Cells $(400 \mu \mathrm{L})$ were harvested at days 1, 3 and 5 and washed in cold phosphatebuffered saline (PBS); centrifuged at $500 \mathrm{x} g$ for 5 min at $25^{\circ} \mathrm{C}$, (Sigma, RCF: 1906; acceleration 19, break 0). Samples were resuspended in $100 \mu \mathrm{L}$ annexin-binding buffer, then $5 \mu \mathrm{L}$ of annexin V Pacific Blue conjugate was added to each $100 \mu \mathrm{L}$ of cell suspension for $15 \mathrm{~min}$ at room temperature in the dark. Then propidium iodide (PI) was added at a final concentration of $2 \mu \mathrm{g} \mathrm{mL} \mathrm{mL}^{-1}$ and cells were mixed gently then incubated for an extra $15 \mathrm{~min}$. At the end of the incubation, an extra $400 \mu \mathrm{L}$ of annexin-binding buffer was added to the cells. Samples were kept on ice protected in the dark until being analysed by flow cytometry. A dye propidium iodide was used to stain dead cells, while a dye annexin V was used for the detection of apoptotic cells. Both dyes allowed the differentiation of dead and apoptotic cells from viable cells.

Reactive oxygen species

Detection of reactive oxygen species and reduced glutathione content in algal cells were assessed using a published methodology (Cossarizza et al. 2009) with some modifications. Briefly, $\mathrm{H}_{2} \mathrm{O}_{2}$ was detected with 2',7'-dichlorodihydrofluorescein diacetate $\left(\mathrm{H}_{2} \mathrm{DCFH}-\mathrm{DA}\right)$ dye using FITC $530 \pm 30 \mathrm{~nm}$ band-pass filter; intracellular superoxide anion $\left(\mathrm{O}_{2}^{-}\right)$was detected with hydroethidine (HE) dye using PE $575 \pm 26 \mathrm{~nm}$ band-pass filter and antioxidant reduced glutathione (GSH), an abundant intracellular nonproteic thiol was detected with monobromobimane (MBB) dye using $450 \pm 50 \mathrm{~nm}$ violet band-pass filter. To avoid dye compensation issues, each fluorescent dye was used individually. Briefly, in separate tubes, $2 \mu \mathrm{M}$ of $\mathrm{H}_{2} \mathrm{DCFH}-$ 
DA was added to $400 \mu \mathrm{L}$ of cells, then gently vortex and incubated for $30 \mathrm{~min} ; 1 \mu \mathrm{M}$ of $\mathrm{HE}$ was added to another tube with $400 \mu \mathrm{L}$ of cells, gently vortex and incubated for $45 \mathrm{~min}$; and $50 \mu \mathrm{M}$ of MBB was added to a new tube with $400 \mu \mathrm{L}$ of cells, gently vortex and incubated for $10 \mathrm{~min}$. All incubation periods were carried out at room temperature protected from the light and then placed on ice until being analysed by flow cytometry.

\section{Statistical analyses}

Statistical analyses were performed using SPSS Statisticsß (IBM) and R Studio (0.99.467). GraphPad Prism (version 6.02) was used to generate the graphs. All results presented in this report were tested against an alpha value of 0.05 . Homogeneity of variances and the normality distribution of the residuals were tested using the Levene and the Shapiro-Wilk normality tests. To follow homogeneity requirements, data were transformed when required. To assess the main effect of increasing temperature and the DNA methylation inhibition drug over time, including their interaction on the different parameters, analysis of variance (ANOVA) was performed. When the main effect was significant, multiple Tukey post hoc comparison tests of the means were performed to locate significant differences. The significance of differences was indicated as $P<0.05$. Throughout the paper, the values given are the mean \pm standard deviation (SD).

\section{Results}

\section{Autofluorescence}

Autofluorescence emission spectra of Symbiodinaceae culture were assessed by confocal microscopy using different lasers (Fig. 2 ; Table 1 ). When excited with a $405 \mathrm{~nm}$ laser, cells were emitting strongly in red due to chlorophyll pigment around $680 \mathrm{~nm}$ (Fig. 2A ). In Figure 2B , cells were excited with two lasers (405 $\mathrm{nm}$ and $488 \mathrm{~nm}$ ) resulting in red and green emissions. Within this overlaying image, we were able to detect differences in pigmentation with one group of cells containing both pigments chlorophyll and accessory pigments (red and green cells; white arrows), whilst other cells contained only one pigment (red or green cells; yellow arrows) and some cells had lost their pigments (blue arrows, Fig. 2B ). To check the level of autofluorescence within cells containing only one pigment (red or green), we completed further analyses focusing on one cell emitting in red only (cell \#1, Fig. 2B ) and two cells emitting only in green (cells \#2 and \# 3, Fig. 2B ). Full emission spectra for these cells excited with $405 \mathrm{~nm}$ laser (cells \#1, \#2 and \#3;Fig. 2B ) and only cell \# 1 excited with lasers (488 nm, $561 \mathrm{~nm}$, and $633 \mathrm{~nm}$ ) were presented in Fig. 2C . Minimal autofluorescence $(450-650 \mathrm{~nm})$ was observed for green cells $(\# 2$ and \#3) and even at a lower level for a red cell (\#1). Strong emission spectra between 650-720 nm corresponding to chlorophyll absorbance can be seen for cell \#1 when excited with laser $405 \mathrm{~nm}$, but also when excited with other lasers (488 nm, $561 \mathrm{~nm}$, and $633 \mathrm{~nm}$ ), while the flat profiles for cells \#2 and \#3 confirmed that those cells are depleted of their chlorophyll content. On the other hand, the presence of abundant chlorophyll in cell \#1 was confirmed with the peaks of emission between $650-700 \mathrm{~nm}$, with maximum intensity observed after excitation with the $405 \mathrm{~nm}$ laser, then with the $561 \mathrm{~nm}$, followed by the $488 \mathrm{~nm}$ laser and the lowest intensity peak was observed with the $633 \mathrm{~nm}$ laser (Fig. 2C ). The differences in the emission intensity of the cells, when excited with four different lasers $(405,488,561$ and $633 \mathrm{~nm})$, were presented in separate micrographs (Fig. 2D ). Maximum intensity was observed with the $405 \mathrm{~nm}$ laser, then with the $561 \mathrm{~nm}$, followed by the $488 \mathrm{~nm}$ laser and the lowest intensity peak was observed with the $633 \mathrm{~nm}$ laser.

\section{Cell enumeration and morphological characterization}

Elevated temperatures, incrementally reached $+7^{\circ} \mathrm{C}$ after $3.5 \mathrm{~h}$ (1-degree increase every $0.5 \mathrm{~h}$ ). The heat stress had a significant impact onSymbiodinaceae cellular growth, cell pigmentation, size, and complexity at different time points, as well as the drug 5-AZA and the interaction between multiple factors (temperature $\mathrm{x}$ drug $\mathrm{x}$ time) in the case of cell size (Fig. 3, Tables S2 and S3). After only one day of heat stress, the algal density dropped for $34 \%$ in the presence of 5-AZA compared to the control conditions $\left(25^{\circ} \mathrm{C}\right.$, plus 5 -AZA), while the opposite trend and $33 \%$ increase was noted in heated cultures without the drug. On days 3 and 5, the algal density reduced in cultures supplemented with 5-AZA for 3.1- and 9-fold respectively, and 3.4- and 9.5-fold without 5-AZA. At control temperature $(25 @ \mathrm{C})$, the algal density including the cell 
numbers positive to chlorophyll $a$ pigment, was slightly increased by day 3 (Tukey $P>0.05$ ) and remained continuous until the end of the experiment (Fig. 3AB ). After 1 day under heat stress, the concentration of algal cell positive for chl $a$ dropped for $35 \%$ with 5 -AZA drug and without the drug, algal density increased by $33 \%$. Further reduction in algal density positive for chl $a$ occurred with prolonged thermal stress with 9and 24-fold drop on day 3 with and without 5-AZA, and over 20,000-fold decrease on day 5 independent on the drug. Both flow-cytometry measurements, using just algal cell numbers and algal cell numbers positive for chl $a$ (excluding bleached cells) were equivalent on day 1 (Fig. 3AB, Table S2 ). However, later values, especially at day 5 , were less consistent for severely reduced cell count as the number of the bleached cell increased.

Heat stress led to an initial increase in cell size for 1.4- and 1.5- fold with and without drug respectively (Tukey $P<0.5$ ), while by prolonged time no difference (Tukey $P>0.5$ ) in size could be noted between treatments by day 5 (Fig. 3C; Table S2 ). An increase in cell size and loss of pigments was also visually observed under a light transmission microscope, with cells increasing in size when exposed to elevated temperature (Fig. 1 ). After an initial increase of $10 \%$ (Tukey $P<0.5$ ), the internal complexity of Symbiodinaceae cells kept at $32 @ \mathrm{C}$ decreased and balanced with control values (Fig. 3D; Table S2 ).

\section{Autofluorescence}

The autofluorescence values were measured for the different emission profiles recorded on a selection of band-pass filters: Cy5-PE $660 \pm 20$-nm, $655 \pm 8$-nm violet and $660 \pm 20$-nm red (Fig. 4 ). The effects of temperature, drug 5-AZA and time on Symbiodinaceaephysiology revealed that all factors had a significant effect on autofluorescence (Table 1, Tables S2 and S3 ). Algal cultures exposed to hyper-thermal stress had a very distinct decrease in autofluorescence, like in the case of Cy5-PE 660-20, a 2- and 1.7-fold drop after day 1 (with and without drugs respectively); followed by a further decrease of a 6.5 - and 12.6 -fold at day 3 , and over a 50 -fold drop by day 5 independent of drug presence. Similar autofluorescence changes were observed when using $655 \pm 8$-nm violet and $660 \pm 20$-nm red filters (Fig. 4 ). In addition, cell emission profiles were recorded on an extra five band-pass filters including FITC 530/30, PI 610/20, 525/50 violet, $605 / 12$ violet, and 525/50 UV-B (Fig. S2). These filters produced autofluorescence patterns with an opposite trend comparing to the other three filters (Cy5-PE $660 \pm 20-\mathrm{nm}, 655 \pm 8$-nm violet, and $660 \pm 20$-nm red) and resulted in increased autofluorescence levels under thermal stress conditions.

\section{Mortality and apoptosis}

The cell viability, evaluated through the percentage of apoptotic (positive for annexin $\mathrm{V}$ dye) and necrotic cells (non-viable cells positive for PI dye), was influenced by thermal stress and time, but not with the addition of the 5-AZA drug (Table 1 and Table S4 ). In cells cultured at $25^{\circ} \mathrm{C}$ without 5-AZA, no significant changes were observed in terms of mortality (percentage of necrotic cells) and apoptosis during the 5 days of the experiment (Table S2A ). Similar observations in the presence of 5 -AZA at $25^{\circ} \mathrm{C}$, with only one exception noted with a significant decrease in apoptotic cell number, between days 3 and 5 (Tukey, $P=0.0315$ ) (Tables S2 and S4 ). Overall at $25^{\circ} \mathrm{C}$, less than $2 \%$ of dead cells and $2-6 \%$ of apoptotic cells were recorded on any given day. Mortality and apoptosis were significantly higher (Tukey, $P<0.0001$ ) in cells kept at $32^{\circ} \mathrm{C}$ from day 1 , with $\sim 20 \%$ of necrotic and over $30 \%$ of apoptotic cells. Compared to the control conditions, this was over a 9 - fold higher $\%$ of cells affected by apoptosis and with over a 12 -fold higher level of mortality. A similar trend was observed at day 3 with up to 7 -fold higher $\%$ of apoptotic cells and up to a 44-fold greater \% of necrotic cells matched to the cultures that were kept under control temperatures. Between the time points, an increase in total mortality of heated cells was observed from day 1 to 3 (Tukey $P<0.0001$ ), with a later decrease from day 3 to 5 at $32^{\circ} \mathrm{C}$ in cells with 5 -AZA (Tukey $P$ $=0.0202$ ) and without the drug (Tukey $P=0.3315$ ). In terms of apoptosis at $32^{\circ} \mathrm{C}$, significant changes were observed, with a decrease from day 1 to 3 , followed by an increase from day 3 to 5 . Under control temperatures, by the end of the experiment, there were only 3-4\% of apoptotic/necrotic cells in total, while under heat stress conditions, over $97 \%$ of algal cells were apoptotic or necrotic (Table S4) .

Reactive oxygen species and glutathione 
Elevated temperatures had a significant main effect on algal cells oxidative stress responses as measured by the production of two ROS molecules: intracellular superoxide anion, hydrogen peroxide, and antioxidant molecule reduced glutathione (Fig. 5 ; Table 1 ). Prolonged exposure to an elevated temperature at $32 @ \mathrm{C}$ resulted in increased ROS production after a 3 - and 5-day period in heated cultures compared to the control samples. On the other hand, the addition of methylation inhibitor drug 5-AZA did not have a significant effect on ROS production (Table 1 ). The $\mathrm{O}_{2}{ }^{-}$levels increased in cells cultured at $32 @ \mathrm{C}$ without 5-AZA by 1.9-, 3.5- and 2.8-fold after 1,3 and 5 days respectively, with similar trends in culture supplemented with the drug (Fig. 5A; Tables S2 ). The $\mathrm{H}_{2} \mathrm{O}_{2}$ levels in cells kept at $32 @ \mathrm{C}$, without 5-AZA were significantly higher than in cells cultured at $25 @ \mathrm{C}$ (Tukey, $P<0.0001$ for both) by 2.4 - and 2.5 -fold at days 3 and 5 respectively (Fig. 5B ; Tables S2 ). An initial decrease in the antioxidant GSH level was detected in cells at $32 @ \mathrm{C}$ by 1.2 - and 1.6-fold with and without 5-AZA respectively. Prolonged thermal stress, increased the GSH production by up to 2.2 fold by day 3 and up to 1.8-fold by day 5 compared to control temperatures.

\section{Pigment composition}

The main effect of temperature and time was observed on the algal pigments, as well as the significant impact of the drug 5-AZA in the case of chl c2 (Three-way ANOVA, Table 1 ). A reduction in algal pigments (pg/cell) was observed with prolonged thermal stress (Fig. 6; Table S2 ). The chl a concentration in cells maintained at $25 @ \mathrm{C}$ remained stable over the 5 days. A decline in the level of chl $a$ for 1.6-, 30- and 202 -fold at days 1, 3 and 5 respectively was with 5-AZA; while a drop for 2-, 60- and the 135-fold was noted under heat stress without 5-AZA. Although we observed a slight decrease in the peridinin concentration in cells kept at $25 @ \mathrm{C}$, these differences were not statistically significant $(P>0.05)$. Under heat stress, the concentration of peridinin pigment in cultures with the drug dropped by 1.8- and 4-fold by day 1 and 3, and 1.9- and 9-fold without the drug. Compared to control cells kept at 25@C, the peridinin concentration in heat-stressed cultures with and without 5-AZA by day 5 reached almost zero levels. A decrease in chlorophyll c2 concentration was observed in cells under heat stress, but not between cells at 25@C. At day 1, in the heated cultures supplemented with the drug, there was a not significant 1.3-fold drop in the chl $c 2$ level (Tukey $P>0.05$ ), while a 1.7 -fold decline was noted in heated cultures without 5-AZA (Tukey $P=0.0038$ ). Further severe decrease in chl $c 2$ levels by 4.7 - and 15 -fold was noted by day 3 in heated algal cells with or without 5 -AZA respectively; by day 5 reached a complete pigment depletion. The concentration of $\beta$-carotene pigment was significantly impacted on the day 1 by thermal stress only in the presence of 5-AZA, while the lack of drug resulted in comparable pigment values as found in cultures under control conditions. Further thermal stress resulted in the complete destruction of $\beta$-carotene independently on the drug presence.

The ratio of pigments diadinoxanthin (Dd) and diatoxanthin (Dt) were used to describe the impact on the xanthophyll cycle throughout the experiment. The main effect of temperature and time was significant on the Dd and Dt ratio. Under the control temperature, a stable ratio was observed during the entire experimental period. Heat stress led to an initial increase in the pigments' ratio resulting in 1.4 and 1.3-fold increase (with and without 5-AZA respectively), followed up by complete decline from day 3 until the end of the experiment.

\section{Discussion}

An organism's ability to tolerate oxidative stress is affected by many factors including its antioxidant capacity (Banerjee \& Roychoudhury 2017) and past environmental history (Middlebrooket al. 2008a). As such, the same external conditions could be potentially beneficial for one and detrimental for another organism, highlighting the importance of understanding the definition of stress as a condition leading to a decrease in an organism's functionality and fitness (Hoffman and Parsons 1991; Bijlsma and Loeschcke 2005). Various mechanisms may increase the ability of organisms to endure stress and epigenetics modifications were recognised to be able to induce the heritable changes resulting in development of phenotypic features allowing organism to adapt to changes happening in the environment (Jablonka \& Raz 2009, Lim \& Brunet 2013, Lamke \& Baurle 2017).

Physiological and oxidative changes were observed in algal cells due to exposure to heat stress and in 
some cases due to the effect of the drug 5-AZA, DNA methylation inhibitor. Our data showed that inSymbiodiniaceae at control temperature 25@C, cell concentration increased over time, which is an expected outcome due to the division of algal cells happening every couple of days. The elevated temperature of $32 @ \mathrm{C}(+7 @ \mathrm{C})$ was recognised as a bleaching threshold for many algal symbionts and the coral-algal symbiosis (Rosic et al. 2011b, Fisher et al. 2012). Two different coral species harbouring different types of algal symbionts also reached the thermal threshold at $32 @ \mathrm{C}$ resulting in bleaching after 5 days of heat stress (Rosic et al. 2020). Using highly sensitive flow cytometry assays, a severe drop in cell numbers was detected after 1 day at $32^{\circ} \mathrm{C}$ only in the presence of 5-AZA (Fig. 3A ). Reversely, without 5-AZA, cell numbers actually increased for $\sim 33 \%$ (Fig. 3 ). The same trend was confirmed in the algal cells positive for chl $a$ (Fig. 3B ). These results suggest about the negative effect of DNA methylation inhibitor 5-AZA on the cell's ability to divide and to survive when facing short-term exposure to heat stress. Heat stress was found to increase cell numbers and promote muscle regeneration in rats (Kojima et al. 2007, Oishi et al. 2009). Many organisms are capable to adapt to some thermal fluctuations by adjusting their thermal tolerance important for cell division processes (Begasse et al. 2015). However, under prolonged thermal stress algal cell cycle was found to be inhibited in the G1 phase of cell division (Fujise et al. 2018). The drug 5-AZA inhibits DNA methylation, and consequently, the loss in DNA methylation may change the regulation of specific genes and their expression (Christman 2002). In plants under heat stress, survival rates were lowered when exposed to the 5-AZA (Ogneva Z.V. 2019). In animal studies, exposure to DNA methylation inhibitors such as 5-AZA, negatively affected the mice and rat fertility when used over a short-term period, while long-term exposure increased the morality of embryos (Raman \& Narayan 1995, Oakes et al. 2007, Rahman et al. 2018). DNA methylation was proposed to be an important mechanism to allow coral adaptation to climate change (Liew et al. 2020). We here demonstrated that when cells were exposed to DNA methylation inhibitor under elevated temperature, these cells decreased division rate resulting in lower algal density. Other processes affected by inhibition of DNA methylation included the changes in cellular size and the pigment chl c2 level, as well as autofluorescence. The autofluorescence profiles of algal cells cultures undergoing thermal stress provide information on the dynamics of photosynthetic pigments such as chlorophyll $a$ and chlorophyllc2 , both specialised in harvesting light, and accessory pigments such as carotenoids that serve photo-protective functions (Olson et al. 1989, Lee et al. 2012).

Physiological changes including oxidative stress response and cell viability were affected by thermal stress and were not affected by the inhibition of methylation processes (presence/absence of 5-AZA). Using sophisticated flow cytometry techniques, we detected the increase in ROS production in living cells in parallel with other physiological responses, as well as a severe reduction in the concentration of the pigment. Oxidative stress was confirmed in all cells exposed to elevated temperatures with increased levels of the ROS molecules, while there was an initial decrease in the levels of the antioxidant, reduced glutathione followed by later increase. The ROS molecules such as hydrogen peroxide play an important role in oxidative stress-induced cellular damage but also cell signalling and regulation of antioxidant enzymes (Veal et al. 2007). Consequently, later increase in the content of GSH, was likely in response to an increase in hydrogen peroxide level. In other organisms, as the outcome of oxidative stress, increased production of ROS and a decreased level of antioxidants have been observed (Halliwell \& Whiteman 2004) and were related to pathogenic conditions (Ozben 2007). Under heat stress, diverse Symbiodinaceae types were reported to differentially increase ROS production (Wietheger et al. 2018).Symbiodinaceae cultures exposed to the sub-lethal thermal stress showed the stable levels of antioxidant GSH, in parallel with an increase in ROS (Krueger et al.2014). However, we detected here an initial reduction in the fluorescent signal corresponding to the antioxidant GSH. Glutathione is the most abundant endogenous antioxidants important for scavenging ROS directly or indirectly (Hwang et al. 1992). This initial drop (at day 1) in the pool of reduced glutathione suggests possible acute stress in algal cells at $32^{\circ} \mathrm{C}$ and active detoxification process as the first line of defence using antioxidants such as GSH to mop the excessive ROS production. On the transcriptomic level, increased expression of genes involved in the antioxidant network such as superoxide dismutase (SOD) and glutathione S-transferase was observed in heated algal cultures at 33@C (Krueger et al. 2014). Later increase in GSH for even up to $220 \%$, suggests about de novosynthesis of GSH. The GSH level is largely determined by de novosynthesis due to the significant increase in GHS intracellular production (Lian et al. 2018). It seems that algal cells 
were directed towards a challenge to mop out the excessive amounts of ROS by inducing further antioxidant production. In terms of cell viability, the percentage of the apoptotic cells inSymbiodinaceae cultures did increase by day 1 of heat stress for $\sim 30 \%$ and $\sim 20 \%$ for the necrotic cells compared to control conditions. However, by day 3 of heat stress, further increase of total apoptotic and necrotic cells reached $70 \%$ and by day 5 over $97 \%$. Some studies suggest that a decrease in mitochondrial GSH level may play a role in signalling during the ROS raise towards cell apoptosis (Armstrong et al. 2002).

The decrease in pigment concentrations was detected very quickly and just after $24 \mathrm{~h}$ of the cells being exposed to $+7 @ \mathrm{C}$ thermal stress. The reduction chlorophyll $a$, peridinin, chlorophyll $c 2$, and beta-carotene concentrations are highly indicative signs of undergoing stress and onset of bleaching. Pigment depletion in algal cultures occurred by day 3 for all analysed pigments indicating photobleaching due to heat stress, but not due to the presence 5-AZA. In symbiotic dinoflagellates, exposure to high temperatures commonly leads to algal photobleaching (Warner et al.1996, 1999, Takahashi et al. 2004). Heat stress at $34^{\circ} \mathrm{C}\left(+9^{\circ} \mathrm{C}\right)$ lasting $24 \mathrm{~h}$ resulted in bleaching inSymbiodinaceae cultures due to the destruction of the chlorophylla-chlorophyll c 2-peridinin-protein complexes (acpPC) (Takahashi et al. 2008). Here, we reported the depletion of the major light-harvesting pigments chlorophyll $a$, chlorophyll $c 2$ and peridinin resulting in photobleaching. These photosynthetic pigments are needed to bind to major antennae proteins acpPC which is an essential part of the thylakoid membranes (Iglesias-Prieto \& Trench 1997). Thermo-sensitive algal cell populations in cultures showed a drop in photosynthetic efficiency and leakage of ROS at 32@C (Levin et al. 2016). A decrease in the functionality of the photosynthetic apparatus has been linked with the cellular increase in ROS content in Symbiodinaceaedinoflagellates exposed to thermal stress (Tchernov et al. 2004, Gardner et al. 2017). Under heat stress, symbiotic dinoflagellates are producing ROS leaking from the mitochondria and chloroplasts resulting in severe cellular damage (Richier et al. 2005, McGinty et al. 2012). However, oxidative stress was found not to be sufficient to lead to coral bleaching without severe damage to the photosystem of algal symbiont (Nielsen et al. 2018). Our data suggest that the ROS production was much higher in heated cells than the ability of the antioxidative system to scavenge ROS, resulting in oxidative stress and cellular damages combined with pigment loss. Under heat stress, symbiotic dinoflagellates are producing ROS leaking from the mitochondria and chloroplasts resulting in severe cellular damage (Richier et al. 2005, McGinty et al. 2012). However, oxidative stress was found not to be sufficient to lead to coral bleaching without severe damage to the photosystem of algal symbiont (Nielsen et al. 2018). Consequently, these data indicate that the ROS production was much higher in heated cells than the ability of the antioxidative system to scavenge ROS, resulting in oxidative stress and cellular damages combined with photobleaching. Symbiotic dinoflagellates previously associated with corals from the warmer reef were more physiologically adaptable to temperature increase than those isolated from the cooler coral reef (Howells et al. 2012) confirming the importance of previous thermal history for organism's heat tolerance (Middlebrook et al.2008).

A better understanding of molecular processes underlining the ability of coral dinoflagellates to adapt and survive in thermally challenged marine environments is critically important for the survival of many hostmicrobe interactions such as cnidarian-Symbiodiniaceaesymbioses and consequently, reef-building corals under anticipated global changes in climate. This is the first scientific study to report cellular, physiological, and oxidative stress responses happening within the Symbiodiniaceae cells during the onset of thermal stress under methylation-compromised conditions. After only a $24 \mathrm{~h}$ period of thermal stress, we report an increase in the production of free radicals $\left(\mathrm{H}_{2} \mathrm{O}_{2}\right.$ and $\left.\mathrm{O}_{2}{ }^{-}\right)$, with a significant drop in the antioxidant GSH level suggesting its use to mop excessive amount of ROS molecules during the oxidative stress response. Prolonged heat stress resulted in loss of pitments, further increase of all measured ROS molecules, and also raise in antioxidant GSH indicating its de novo synthesis and the deepening of cellular damage. Our findings demonstrated the positive effect of DNA methylation on the cell division and dinoflagellate size during the onset of heat stress. When DNA methylation was compromised, coral dinoflagellates were earlier losing the battle for survival and the ability to adapt under heat stress. Consequently, algal plasticity and adaptability may be facilitated to some extent via epigenetic modifications.

\section{References}


An G.H., Bielich J., Auerbach R. \& Johnson E.A., 1991. Isolation and characterization of carotenoid hyperproducing mutants of yeast by flow cytometry and cell sorting. Nat Biotechnol 9, 70-3.

An G.H., Suh O.S., Kwon H.C., Kim K. \& Johnson E.A., 2000. Quantification of carotenoids in cells of Phaffia rhodozyma by autofluorescence. Biotechnol Lett 22, 1031-4.

Armstrong J.S., Steinauer K.K., Hornung B., Irish J.M., Lecane P., Birrell G.W., Peehl D.M. \& Knox S.J., 2002. Role of glutathione depletion and reactive oxygen species generation in apoptotic signaling in a human B lymphoma cell line. Cell Death \& Differentiation 9, 252-63.

Banerjee A. \& Roychoudhury A., 2017. Abiotic stress, generation of reactive oxygen species, and their consequences: An overview. In: Reactive Oxygen Species in Plants: Boon Or Bane - Revisiting the Role of ROS (pp. 23-50.

Begasse Maria L., Leaver M., Vazquez F., Grill Stephan W. \& Hyman Anthony A., 2015. Temperature Dependence of Cell Division Timing Accounts for a Shift in the Thermal Limits of C. elegans and C. briggsae. Cell Reports 10, 647-53.

Camp E.F., Schoepf V., Mumby P.J., Hardtke L.A., Rodolfo-Metalpa R., Smith D.J. \& Suggett D.J., 2018. The future of coral reefs subject to rapid climate change: Lessons from natural extreme environments. Frontiers in Marine Science 5

Chodavarapu R.K., Feng S., Ding B., Simon S.A., Lopez D., Jia Y., Wang G.L., Meyers B.C., Jacobsen S.E. \& Pellegrini M., 2012. Transcriptome and methylome interactions in rice hybrids. Proc Natl Acad Sci U S A $109,12040-5$.

Christman J.K., 2002. 5-Azacytidine and 5-aza-2'-deoxycytidine as inhibitors of DNA methylation: mechanistic studies and their implications for cancer therapy. Oncogene 21, 5483-95.

Cossarizza A., Ferraresi R., Troiano L., Roat E., Gibellini L., Bertoncelli L., Nasi M. \& Pinti M., 2009. Simultaneous analysis of reactive oxygen species and reduced glutathione content in living cells by polychromatic flow cytometry. Nat Protoc 4, 1790-7.

de Mendoza A., Bonnet A., Vargas-Landin D.B., Ji N., Li H., Yang F., Li L., Hori K., Pflueger J., Buckberry S., Ohta H., Rosic N., Lesage P., Lin S. \& Lister R., 2018. Recurrent acquisition of cytosine methyltransferases into eukaryotic retrotransposons. Nat Commun 9, 1341.

Dineen J., 2001. Indian River Lagoon Species Inventory.

Douglas A.E., 2003. Coral bleaching-how and why? Mar Pollut Bull 46, 385-92.

Dunn S.R., Pernice M., Green K., Hoegh-Guldberg O. \& Dove S.G., 2012. Thermal stress promotes host mitochondrial degradation in symbiotic cnidarians: are the batteries of the reef going to run out? PloS one 7, e39024-e.

Eirin-Lopez J.M. \& Putnam H.M., 2019. Marine Environmental Epigenetics. Annual Review of Marine Science 11, 335-68.

Fisher P.L., Malme M.K. \& Dove S., 2012. The effect of temperature stress on coral-Symbiodinium associations containing distinct symbiont types. Coral Reefs 31, 473-85.

Fujise L., Nitschke M.R., Frommlet J.C., Serôdio J., Woodcock S., Ralph P.J. \& Suggett D.J., 2018. Cell Cycle Dynamics of Cultured Coral Endosymbiotic Microalgae (Symbiodinium) Across Different Types (Species) Under Alternate Light and Temperature Conditions. Journal of Eukaryotic Microbiology 65, 505-17.

Gardner S.G., Raina J.B., Ralph P.J. \& Petrou K., 2017. Reactive oxygen species (ROS) and dimethylated sulphur compounds in coral explants under acute thermal stress. J Exp Biol 220, 1787-91.

Gates R.D., Baghdasarian G. \& Muscatine L., 1992. Temperature stress causes host cell detachment in symbiotic cnidarians: implications for coral bleaching. Biological Bulletin 182, 324-32. 
Gattuso J.-P., Allemand D. \& Frankignoulle M., 1999. Photosynthesis and Calcification at Cellular, Organismal and Community Levels in Coral Reefs: A Review on Interactions and Control by Carbonate Chemistry1. Integrative and Comparative Biology 39, 160-83.

Gierz S.L., Foret S. \& Leggat W., 2017. Transcriptomic Analysis of Thermally Stressed Symbiodinium Reveals Differential Expression of Stress and Metabolism Genes. Front Plant Sci 8, 271.

Gordon B.R. \& Leggat W., 2010. Symbiodinium-invertebrate symbioses and the role of metabolomics. Mar Drugs 8, 2546-68.

Guillard R.R. \& Ryther J.H., 1962. Studies of marine planktonic diatoms. I. Cyclotella nana Hustedt, and Detonula confervacea (cleve) Gran. Can J Microbiol 8, 229-39.

Halliwell B. \& Whiteman M., 2004. Measuring reactive species and oxidative damage in vivo and in cell culture: how should you do it and what do the results mean? Br J Pharmacol 142, 231-55.

Hoegh-Guldberg O., 1999. Climate change, coral bleaching and the future of the world's coral reefs. Marine and Freshwater Research 50, 839-66.

Hoegh-Guldberg O., Mumby P.J., Hooten A.J., Steneck R.S., Greenfield P., Gomez E., Harvell C.D., Sale P.F., Edwards A.J., Caldeira K., Knowlton N., Eakin C.M., Iglesias-Prieto R., Muthiga N., Bradbury R.H., Dubi A. \& Hatziolos M.E., 2007a. Coral reefs under rapid climate change and ocean acidification. Science (New York, N.Y.) 318, 1737-42.

Hoegh-Guldberg O., Mumby P.J., Hooten A.J., Steneck R.S., Greenfield P., Gomez E., Harvell C.D., Sale P.F., Edwards A.J., Caldeira K., Knowlton N., Eakin C.M., Iglesias-Prieto R., Muthiga N., Bradbury R.H., Dubi A. \& Hatziolos M.E., 2007b. Coral reefs under rapid climate change and ocean acidification. Science $318,1737-42$.

Hoegh-Guldberg O., Poloczanska E.S., Skirving W. \& Dove S., 2017. Coral reef ecosystems under climate change and ocean acidification. Frontiers in Marine Science 4

Howells E.J., Beltran V.H., Larsen N.W., Bay L.K., Willis B.L. \& van Oppen M.J.H., 2012. Coral thermal tolerance shaped by local adaptation of photosymbionts. Nature Climate Change 2, 116-20.

Hughes D.J., Alderdice R., Cooney C., Kühl M., Pernice M., Voolstra C.R. \& Suggett D.J., 2020. Coral reef survival under accelerating ocean deoxygenation. Nature Climate Change 10, 296-307.

Hwang C., Sinskey A.J. \& Lodish H.F., 1992. Oxidized redox state of glutathione in the endoplasmic reticulum. Science 257, 1496-502.

Iglesias-Prieto R. \& Trench R.K., 1997. Acclimation and adaptation to irradiance in symbiotic dinoflagellates. II. Response of chlorophyll-protein complexes to different photon-flux densities. Marine Biology 130, 23-33.

Jablonka E. \& Raz G., 2009. Transgenerational epigenetic inheritance: prevalence, mechanisms, and implications for the study of heredity and evolution. Q Rev Biol 84, 131-76.

Kojima A., Goto K., Morioka S., Naito T., Akema T., Fujiya H., Sugiura T., Ohira Y., Beppu M., Aoki H. \& Yoshioka T., 2007. Heat stress facilitates the regeneration of injured skeletal muscle in rats. J Orthop Sci $12,74-82$.

Krueger T., Becker S., Pontasch S., Dove S., Hoegh-Guldberg O., Leggat W., Fisher P.L. \& Davy S.K., 2014. Antioxidant plasticity and thermal sensitivity in four types of Symbiodinium sp. J Phycol 50, 1035-47.

Krueger T., Hawkins T.D., Becker S., Pontasch S., Dove S., Hoegh-Guldberg O., Leggat W., Fisher P.L. \& Davy S.K., 2015. Differential coral bleaching-Contrasting the activity and response of enzymatic antioxidants in symbiotic partners under thermal stress. Comp Biochem Physiol A Mol Integr Physiol 190, 15-25. 
LaJeunesse T.C., Parkinson J.E., Gabrielson P.W., Jeong H.J., Reimer J.D., Voolstra C.R. \& Santos S.R., 2018. Systematic Revision of Symbiodiniaceae Highlights the Antiquity and Diversity of Coral Endosymbionts. Current Biology 28, 2570-80.

Lamke J. \& Baurle I., 2017. Epigenetic and chromatin-based mechanisms in environmental stress adaptation and stress memory in plants. Genome Biol 18, 124.

Lee C.S., Wilson Yeo Y.S. \& Sin T.M., 2012. Bleaching response of Symbiodinium (zooxanthellae): Determination by flow cytometry. Cytometry Part A 81 A, 888-95.

Leggat W., Seneca F., Wasmund K., Ukani L., Yellowlees D. \& Ainsworth T.D., 2011. Differential responses of the coral host and their algal symbiont to thermal stress. PLoS One 6, e26687.

Lesser M.P., 1996. Elevated temperatures and ultraviolet radiation cause oxidative stress and inhibit photosynthesis in symbiotic dinoflagellates. Limnology and Oceanography 41, 271-83.

Lesser M.P., 2006. Oxidative stress in marine environments: biochemistry and physiological ecology. Annu Rev Physiol 68, 253-78.

Levin R.A., Beltran V.H., Hill R., Kjelleberg S., McDougald D., Steinberg P.D. \& van Oppen M.J., 2016a. Sex, Scavengers, and Chaperones: Transcriptome Secrets of Divergent Symbiodinium Thermal Tolerances. Mol Biol Evol 33, 3032.

Levin R.A., Beltran V.H., Hill R., Kjelleberg S., McDougald D., Steinberg P.D. \& van Oppen M.J., 2016b. Sex, Scavengers, and Chaperones: Transcriptome Secrets of Divergent Symbiodinium Thermal Tolerances. Mol Biol Evol 33, 2201-15.

Li Y., Liew Y.J., Cui G., Cziesielski M.J., Zahran N., Michell C.T., Voolstra C.R. \& Aranda M., 2018. DNA methylation regulates transcriptional homeostasis of algal endosymbiosis in the coral model Aiptasia. Science Advances 4, eaat2142.

Lian G., Gnanaprakasam J.N.R., Wang T., Wu R., Chen X., Liu L., Shen Y., Yang M., Yang J., Chen Y., Vasiliou V., Cassel T.A., Green D.R., Liu Y., Fan T.W.M. \& Wang R., 2018. Glutathione de novo synthesis but not recycling process coordinates with glutamine catabolism to control redox homeostasis and directs murine $\mathrm{T}$ cell differentiation. eLife 7

Liew Y.J., Howells E.J., Wang X., Michell C.T., Burt J.A., Idaghdour Y. \& Aranda M., 2020. Intergenerational epigenetic inheritance in reef-building corals. Nature Climate Change 10, 254-9.

Liew Y.J., Zoccola D., Li Y., Tambutté E., Venn A.A., Michell C.T., Cui G., Deutekom E.S., Kaandorp J.A., Voolstra C.R., Forêt S., Allemand D., Tambutté S. \& Aranda M., 2018. Epigenome-associated phenotypic acclimatization to ocean acidification in a reef-building coral. Science Advances 4, eaar8028.

Lim J.P. \& Brunet A., 2013. Bridging the transgenerational gap with epigenetic memory. Trends Genet 29, $176-86$.

Martindale J.L. \& Holbrook N.J., 2002. Cellular response to oxidative stress: signaling for suicide and survival. J Cell Physiol 192, 1-15.

McGinty E.S., Pieczonka J. \& Mydlarz L.D., 2012. Variations in reactive oxygen release and antioxidant activity in multiple Symbiodinium types in response to elevated temperature. Microb Ecol 64, 1000-7.

Middlebrook R., Hoegh-Guldberg O. \& Leggat W., 2008a. The effect of thermal history on the susceptibility of reef-building corals to thermal stress. J Exp Biol 211, 1050-6.

Middlebrook R., Hoegh-Guldberg O. \& Leggat W., 2008b. The effect of thermal history on the susceptibility of reef-building corals to thermal stress. Journal of Experimental Biology 211, 1050-6.

Muscatine L., Pool R.R. \& Trench R.K., 1975. Symbiosis of algae and invertebrates: aspects of the symbiont surface and the host-symbiont interface. Transactions of the American Microscopical Society 94, 450-69. 
Muscatine L. \& Porter J.W., 1977. Reef corals - mutualistic symbioses adapted

to nutrient-poor environments. Bioscience 27, 454-60.

Nielsen D.A., Petrou K. \& Gates R.D., 2018. Coral bleaching from a single cell perspective. ISME J 12, 1558-67.

Oakes C.C., Kelly T.L.J., Robaire B. \& Trasler J.M., 2007. Adverse Effects of 5-Aza-2'-Deoxycytidine on Spermatogenesis Include Reduced Sperm Function and Selective Inhibition of de Novo DNA Methylation. Journal of Pharmacology and Experimental Therapeutics 322, 1171-80.

Ogneva Z.V. S.A.R., Dubrovina A.S., Kiselev K.V. , 2019. Effect of 5-azacytidine induced DNA demethylation on abiotic stress tolerance in Arabidopsis thaliana. Plant Protection Science 55

Oishi Y., Hayashida M., Tsukiashi S., Taniguchi K., Kami K., Roy R.R. \& Ohira Y., 2009. Heat stress increases myonuclear number and fiber size via satellite cell activation in rat regenerating soleus fibers. J Appl Physiol (1985) 107, 1612-21.

Olson RJ Z.E., Durand MD, 1993. Phytoplankton analysis using flow cytometry. In: Handbook of Methods in Aquatic Microbial Ecology (ed. by Kemp PF SB, Sherr EB, Cole JJ,), pp. 175-86. Lewis Publishers, Florida.

Olson R.J., Zettler E.R. \& Anderson O.K., 1989. Discrimination of eukaryotic phytoplankton cell types from light scatter and autofluorescence properties measured by flow cytometry. Cytometry 10, 636-43.

Ozben T., 2007. Oxidative stress and apoptosis: Impact on cancer therapy. Journal of Pharmaceutical Sciences 96, 2181-96.

Premazzi G., Buonaccorsi G. \& Zilio P., 1989. Flow cytometry for algal studies. Water Res 23, 431-42.

Rahman M.B., Schellander K., Luceno N.L. \& Van Soom A., 2018. Heat stress responses in spermatozoa: Mechanisms and consequences for cattle fertility. Theriogenology 113, 102-12.

Raman R. \& Narayan G., 1995. 5-aza deoxycytidine-induced inhibition of differentiation of spermatogonia into spermatocytes in the mouse. Molecular Reproduction and Development 42, 284-90.

Richier S., Furla P., Plantivaux A., Merle P.L. \& Allemand D., 2005. Symbiosis-induced adaptation to oxidative stress. J Exp Biol 208, 277-85.

Rosic N., Kaniewska P., Chan C.K., Ling E.Y., Edwards D., Dove S. \& Hoegh-Guldberg O., 2014. Early transcriptional changes in the reef-building coral Acropora aspera in response to thermal and nutrient stress. BMC Genomics 15, 1052.

Rosic N., Ling E.Y.S., Chan C.K.K., Lee H.C., Kaniewska P., Edwards D., Dove S. \& Hoegh-Guldberg O., 2015. Unfolding the secrets of coral-Algal symbiosis. ISME Journal 9, 844-56.

Rosic N., Remond C. \& Mello-Athayde M.A., 2020. Differential impact of heat stress on reef-building corals under different light conditions. Marine Environmental Research, 104947.

Rosic N.N., Leggat W., Kaniewska P., Dove S. \& Hoegh-Guldberg O., 2013. New-old hemoglobin-like proteins of symbiotic dinoflagellates. Ecol Evol 3, 822-34.

Rosic N.N., Pernice M., Dove S., Dunn S. \& Hoegh-Guldberg O., 2011a. Gene expression profiles of cytosolic heat shock proteins Hsp70 and Hsp90 from symbiotic dinoflagellates in response to thermal stress: possible implications for coral bleaching. Cell Stress Chaperones 16, 69-80.

Rosic N.N., Pernice M., Dunn S., Dove S. \& Hoegh-Guldberg O., 2010. Differential regulation by heat stress of novel cytochrome P450 genes from the dinoflagellate symbionts of reef-building corals. Appl Environ Microbiol 76, 2823-9. 
Rosic N.N., Pernice M., Rodriguez-Lanetty M. \& Hoegh-Guldberg O., 2011b. Validation of housekeeping genes for gene expression studies in Symbiodinium exposed to thermal and light stress. Mar Biotechnol (NY) $13,355-65$.

Salas BH H.J., Strychar KB, Ostrom PH, Cervino JM, 2017. Site-specific variation in gene expression from Symbiodinium spp. associated with offshore and inshore Porites astreoides in the lower Florida Keys is lost with bleaching and disease stress. PloS one 12(3)

Suzuki M.M. \& Bird A., 2008. DNA methylation landscapes: provocative insights from epigenomics. Nat Rev Genet 9, 465-76.

Takahashi S., Nakamura T., Sakamizu M., Van Woesik R. \& Yamasaki H., 2004. Repair Machinery of Symbiotic Photosynthesis as the Primary Target of Heat Stress for Reef-Building Corals. Plant and Cell Physiology 45, 251-5.

Takahashi S., Whitney S., Itoh S., Maruyama T. \& Badger M., 2008. Heat stress causes inhibition of the de novo synthesis of antenna proteins and photobleaching in cultured Symbiodinium. Proceedings of the National Academy of Sciences of the United States of America 105, 4203-8.

Tammen S.A., Friso S. \& Choi S.W., 2012. Epigenetics: The link between nature and nurture. Mol Aspects Med

Tchernov D., Gorbunov M.Y., De Vargas C., Yadav S.N., Milligant A.J., Haggblom M. \& Falkowski P.G., 2004. Membrane lipids of symbiotic algae are diagnostic of sensitivity to thermal bleaching in corals. Proceedings of the National Academy of Sciences of the United States of America 101, 13531-5.

Veal E.A., Day A.M. \& Morgan B.A., 2007. Hydrogen peroxide sensing and signaling. Mol Cell 26, 1-14.

Warner M.E., Fitt W.K. \& Schmidt G.W., 1996. The effects of elevated temperature on the photosynthetic efficiency of zooxanthellae in hospite from four different species of reef coral: a novel approach. Plant, Cell \& Environment 19, 291-9.

Warner M.E., Fitt W.K. \& Schmidt G.W., 1999. Damage to photosystem II in symbiotic dinoflagellates: A determinant of coral bleaching. Proceedings of the National Academy of Sciences of the United States of America 96, 8007-12.

Weis V.M. \& Allemand D., 2009. What determines coral health? Science 324, 1153-5.

Wietheger A., Starzak D.E., Gould K.S. \& Davy S.K., 2018. Differential ROS Generation in Response to Stress in Symbiodinium spp. The Biological Bulletin 234, 11-21.

Winnefeld M. \& Lyko F., 2012. The aging epigenome: DNA methylation from the cradle to the grave. Genome Biol 13, 165.

Yellowlees D., Rees T.A.V. \& Leggat W., 2008. Metabolic interactions between algal symbionts and invertebrate hosts. Plant, Cell and Environment 31, 679-94.

Zapata M., Rodriguez F. \& Garrido J.L., 2000. Separation of chlorophylls and carotenoids from marine phytoplankton: A new HPLC method using a reversed phase C8 column and pyridine-containing mobile phases. Marine Ecology Progress Series 195, 29-45.

\section{List of Figures and Tables}

Table 1. Statistical analysis (three-way ANOVA) of the effects of temperature, drug and time on the physiology and oxidative stress response of Symbiodinaceae. The measurements of algal density, autoflorescence, ROS, glutathione and cell viability were done using flow cytometry $(\mathrm{n}=3)$, while the levels of the pigments were evaluated using HPLC $(\mathrm{n}=5)$. *Indicates significant effects at $P<0.05$.

Supplementary Table 1. Summary of the specifications used in this study - voltage for each parameter (or channel) used to assess cells autofluorescence and concentration (A); apoptosis and mortality (B); and 
reactive oxygen species and antioxidant $(\mathrm{C})$. Note that for cells autofluorescence and density a stopping gate of 1000 beads was set; a total of 50,000 cells and 20,000 cells were analysed for apoptosis/mortality and ROS/antioxidant analysis respectively. The threshold was set on FSC at 500 for all experiments.

Supplementary Table 2. Multiple Comparisons (ANOVA) between days 1, 3 and 5 at each temperature in the presence or absence of the drug (A); multiple comparisons between treatments (temperature $+/-$ the presence of the drug) at day 1, 3 and 5 (B). Note: ROS, cell count, cell size: FSC, cell complexity: SSC, apoptosis, and mortality obtained by flow-cytometry and pigment concentrations by HPLC.

Supplementary Table 3. The impact of DNA methylation inhibitor 5-AZA-2'-deoxycytidine (5-AZA) on Symbiodiniaceae morphology (size \& complexity), cell number, specific growth rate, autofluorescence, ROS \& antioxidant production, mortality, apoptosis and pigment concentrations following heat stress. Analysis was done on Prism using two-way ANOVAs with repeated measures (Tukey test for correct multiple comparison tests).

Supplementary Table 4. Percentage of cells positive for propidium iodide (PI) were representatives of cell mortality (\%) and cells positive for Annexin V were representatives of apoptotic cells (\%). All data were given as the mean values from three independent biological replicates (+-SD).

Figures

Figure 1. (A) Culture of Symbiodiniaceae cells (formerSymbiodinium clade B; ITS2 type B2) composed predominantly of healthy pigmented cells observed under light microscopy after one-day exposure to normal temperature (25deg C) without the addition of DNA methylation inhibitor 5-AZA-2'-deoxycytidine (5AZA) [scale $50 \mu \mathrm{m}$, objective 20X]. (B) Replicate culture composed of a mixture of healthy \& bleached Symbiodiniaceae cells after one-day exposure to elevated temperature $\left(32^{\circ} \mathrm{C}\right)$ without 5 -AZA. Note the presence of enlarged apoptotic cells with complete loss of pigmentation (blue arrows), healthy cell (red arrows) and cell undergoing thermal stress with almost complete loss of its pigmentation (black arrow) [Scale $50 \mu \mathrm{m}$, objective 40X].

Figure 2. Autofluorescent emission spectra of Symbiodiniaceae cultures analysed by confocal microscopy (Zeiss LSM 710). (A) Micrograph showing the cells emitting around $680 \mathrm{~nm}$ when excited with a $405 \mathrm{~nm}$ laser. (B) The same field of view as in picture A presented as an overlay of images that included the brightfield plus emission images when excited with the $405 \mathrm{~nm}$ and $488 \mathrm{~nm}$ lasers. Different levels of pigmentation can be observed with some cells containing both chlorophyll (red cells) and accessory pigments (green cells) as indicated by white arrows; other cells contained only one pigment (red or green cells) as indicated by yellow arrows and some cells had no pigments (cells indicated by blue arrows). (C) For further analysis, we selected one cell with high red autofluorescence (from picture B cell \#1 B) and two cells with only green fluorescence (from picture B cells \#2 and 3) and reported their emission wavelengths and relative intensity when excited with the $405 \mathrm{~nm}$ laser, corresponding to the spectrum $405 \mathrm{~nm}$ cell 1, $405 \mathrm{~nm}$ cell 2 and 405 nm cell 3 respectively. (D) Each micrograph shows the maximum emission intensity of cell \#1 when excited with different lasers (405nm; 488nm; $561 \mathrm{~nm}$ and $633 \mathrm{~nm})$. The objective used for micrographs was 20x.

Figure 3. The effect of thermal stress and DNA methylation inhibition on (A) the concentration of single viableSymbiodiniaceae cells per $\mathrm{mL}$, (B) concentration ofSymbiodiniaceae cells positive for chlorophyll when using a $660+/-20 \mathrm{~nm}$ bandpass filter, (C) algal cell size (FSC), and (D) cells internal complexity (SSC) after incubation at elevated temperature $(32 @ \mathrm{C})$ compared to normal temperature $(25 @ \mathrm{C})$ in the presence or absence of a DNA methylation inhibitor during a five-day period. Data points represent the mean values $( \pm \mathrm{SD})$ from three biological replicates. $P<0.5$; ANOVA.

Figure 4. The effects of temperature and 5-AZA on the autofluorescence profiles of Symbiodiniaceae assessed by flow cytometry. Pigments contained within the cells were excited with five individual lasers (UV, 407, 488, 561, $633 \mathrm{~nm}$ ). Emission signals were collected using the following band-pass filters: (A) Cy5-PE (660/20); (B) 655/8 Violet; and (C) 660/20 Red, all activated in logarithmic scale. Data points represent the mean values $( \pm \mathrm{SD})$ from three biological replicates. Values were expressed in flow cytometry arbitrary units. $P<$ 


\section{5 ; ANOVA.}

Figure 5. The effects of temperature and 5-AZA on the production of reactive oxygen species: (A) intracellular superoxide anion $\left(\mathrm{O}_{2}{ }^{-}\right)$detected using hydroethidine (HE); (B) $\mathrm{H}_{2} \mathrm{O}_{2}$ detected with 2',7'dichlorodihydrofluorescein diacetate $\left(\mathrm{H}_{2} \mathrm{DCFH}-\mathrm{DA}\right)$; and $(\mathrm{C})$ antioxidant reduced glutathione (GSH) detected using monobromobimane (MBB). Mean values (+-SD) were expressed in flow cytometry arbitrary units from three biological replicates. To avoid dyes' compensation issues, each fluorescent dye was tested independently from each other. Baseline levels of autofluorescence from unstained samples for each parameter were recorded and removed from the analysis. $P<0.5$; ANOVA.

Figure 6. Pigments concentrations (pg/cell) in cell culture ofSymbiodiniaceae exposed to control (25deg C) and thermal stress conditions (32deg C) with and without DNA methylation inhibitor 5-AZA-2'deoxycytidine (5-AZA) during a 5-day period included: (A) chlorophyll $a$, (B) peridinin; (C) chlorophyll c2; (D) $\beta$-carotene concentrations and (E) Dt/(Dt+Dd) ratio. Pigment concentrations were normalised and presented per algal cell $\left(\mathrm{pg} \mathrm{cell}^{-1}\right.$ ), while pigment ratio Diadinoxanthin (Dd) and Diatoxanthin (Dt) were used to provide information about xanthophyll cycle during the duration of the experiment. All data were given as the mean values from five independent biological replicates $( \pm \mathrm{SD})$. Values were considered significantly different if the $P$-value was $<0.05$ (detailed statistics is provided in Table 1 and Supplementary Table 2).

Supplementary Figure 1. Gating strategy for the acquisition and analysis of Symbiodiniaceae cells. (A) Dot plot with side scatter (SSC-A) on the y-axis and forward scatter (FSC-A) on the x-axis (both in logarithmic scales). Gate was created around the population of interest (old nameSymbiodinium ), accumulation bodies and debris (for removal), and beads. (B) Dot plot with a $525 \pm 50$-nm band-pass filter parameter on the $\mathrm{y}$-axis and FSC-A on the $\mathrm{x}$-axis to allow a clear separation between the beads and the rest of the cells. A gate was created around the beads, which is then used as the stopping gate during acquisition for cell enumeration and autofluorescence analysis. (C) Cellular debris, accumulation bodies, and noise can be removed fromSymbiodiniaceae cells based on the red fluorescence of the chlorophyll content within the cells using a red laser $(633 \mathrm{~nm})$ and the $660 \pm 20-\mathrm{nm}$ band-pass filter; only the Symbiodiniaceae population is displayed; note that some cells have a high level of fluorescence, while other are completely bleached. (D) Doublet cells were removed from acquisition and analysis by creating a new dot plot selecting the forward scatter width (FSC-W) on the y-axis and the forward scatter height (FSC-H) on the $\mathrm{x}$-axis. The dense population inside the tight rectangle gate is composed of single cells; note that a similar procedure was repeated for every population of interest including the beads. Once voltages have been set and single-cell populations defined, acquisition data was recorded. Single beads population was used as the stopping gate (1000 events) and all events as a storage gate.

Supplementary Figure 2. The effects of temperature and 5-AZA on the remaining autofluorescence profiles of Symbiodiniaceaeassessed by flow cytometry. Pigments contained within the cells were excited with five individual lasers (UV, 407, 488, 561, $633 \mathrm{~nm}$ ) and emission signals collected using the following band-pass filters: (A) FITC 530/30; (B) PI 610/20; (C) Cy5-PE 660/20; (D) 525/50 violet; (E) 605/12 violet; (F) 655/8 violet; (G) 525/50 UV-B; and (H) 660/20 red. All band-pass filter voltages (Table 1) were activated in the logarithmic scale. Mean values $( \pm \mathrm{SD})$ are expressed in flow cytometry arbitrary units from three biological replicates.

Acknowledgment: Simon Bloomberg for the statistical support and Osborne Geoffrey and Virginia Nink for the flow cytometry support. Thanks to Andrew Taylor for his work in the initial stages of this project and Dr Linda Tonk for her help in confirming the genotype of the symbiotic dinoflagellates.

\section{Hosted file}

2020 All_figures_together_final.pdf available at https://authorea.com/users/319775/articles/ 449485-heat-stress-in-symbiotic-dinoflagellates-signalling-towards-life-or-death 


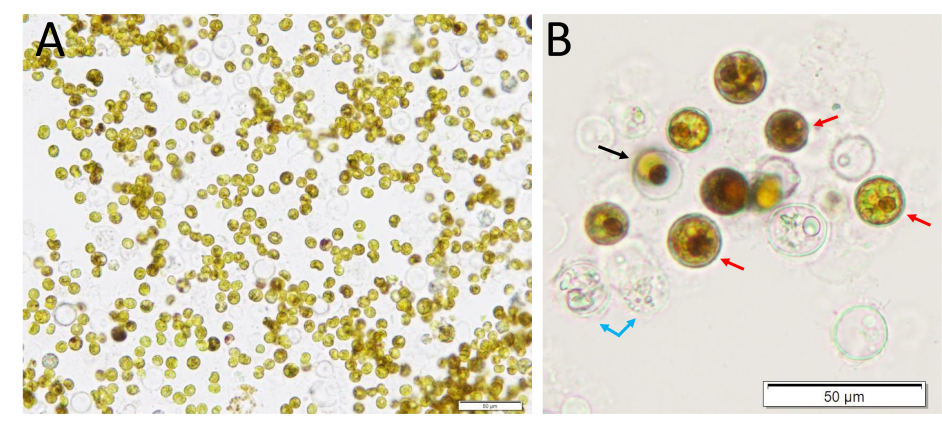

Figure 1. (A) Culture of Symbiodiniaceae cells (former Symbiodinium clade B; ITS2 type B2) composed predominantly of healthy pigmented cells observed under light microscopy after one-day exposure to normal temperature $\left(25^{\circ} \mathrm{C}\right)$ without the addition of DNA methylation inhibitor 5-AZA-2'-deoxycytidine (5-AZA) [scale $50 \mu \mathrm{m}$, objective 20X]. (B) Replicate culture composed of a mixture of healthy \& bleached Symbiodiniaceae cells after one-day exposure to elevated temperature $\left(32^{\circ} \mathrm{C}\right)$ without 5-AZA. Note the presence of enlarged apoptotic cells with complete loss of pigmentation (blue arrows), healthy cell (red arrows) and cell undergoing thermal stress with almost complete loss of its pigmentation (black arrow) [Scale $50 \mu \mathrm{m}$, objective 40X].

\section{Hosted file}

2020 All_tables_together_final.pdf available at https://authorea.com/users/319775/articles/ 449485-heat-stress-in-symbiotic-dinoflagellates-signalling-towards-life-or-death 

Table 1. Statistical analysis (three-way ANOVA) of the effects of temperature, drug and time on the physiology and oxidative stress response of Symbiodinaceae.
The measurements of algal density, autoflorescence, RoS, glutathione and cell viability were done using flow cytometry (n=3), while the levels of the pigments were evaluated using HPLC (n=5). * *ndicates significant effects at $P<0.05$.

\begin{tabular}{|c|c|c|c|c|c|c|}
\hline Variables & $\begin{array}{c}\text { Symbiodinaceae } \\
\text { concentration }\end{array}$ & $\begin{array}{l}\text { Symbio concentration } \\
+c h \mid 660 / 20\end{array}$ & 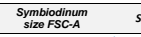 & Symbio complexity SSC & $\begin{array}{c}\text { Appoptosis } \\
\text { (\% cells positive) }\end{array}$ & $\begin{array}{l}\text { Dead/necrotic cells } \\
\text { (\% cells positive) }\end{array}$ \\
\hline $\begin{array}{c}\text { Temperature } \\
\text { Drug } \\
\text { Time }\end{array}$ & 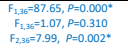 & 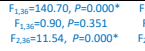 & 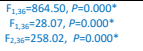 & 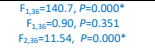 & 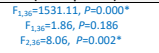 & 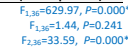 \\
\hline $\begin{array}{l}\text { Temperaturex } \\
\text { Drug } x \text { Time }\end{array}$ & $\mathrm{F}_{233}=2.40, \rho=0.111$ & $F_{236}=2.66, P=0.090$ & $F_{236}=13.06, P=0.000^{*}$ & $F_{236}=2.66, P=0.090$ & $F_{2,36}=1.62, P=0.219$ & $9, P=0.749$ \\
\hline Variables & CYS.PE 660-20 & $655 / 8$ violet & 660/20 Red & $\begin{array}{l}\text { Mean o2- content }-H E \\
\text { flloorescence }\end{array}$ & $\begin{array}{l}\text { Mean H2O2 content - } \mathrm{H2}-\mathrm{H} \\
\text { DA fluorescenee }\end{array}$ & Mean GSH content - \\
\hline $\begin{array}{c}\text { Temperature } \\
\text { Prug } \\
\text { Time } \\
\text { Temperature }\end{array}$ & 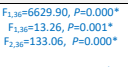 & 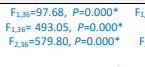 & 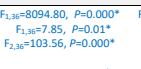 & 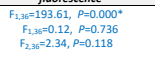 & 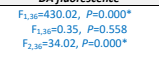 & 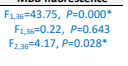 \\
\hline Drug x Time & $F_{2,36}=9.06, P=0.001^{*}$ & $F_{23 s=178.71,} P=0.000^{*}$ & $F_{2,36}=6.78, \rho=0.005^{*}$ & $F_{2,36}=0.59, P=0.560$ & $F_{2.36}=0.25, P=0.783$ & $F_{2,36}=0.76, P=0.477$ \\
\hline Variables & Chla a pg/cell) & Peridinin (pg/cell) & Chlc2 (pg/cell) & Beta-carotene (pg/cell) & $D t /(D t+D d)$ & \\
\hline $\begin{array}{l}\text { Temperature } \\
\text { Drug } \\
\text { Time } \\
\text { Time } \\
\end{array}$ & 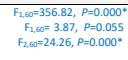 & 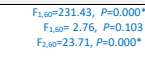 & 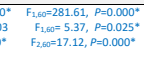 & 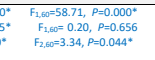 & 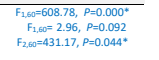 & \\
\hline Drug x Time & $F_{2,00}=0.41, \rho=0.663$ & $F_{2,50}=0.10, P=0.904$ & $F_{2,00}=0.60, P=0.551$ & $F_{2,60}=2.14, \rho=0.129$ & $F_{2,60}=0.34, P=0.712$ & \\
\hline
\end{tabular}

